\title{
Ampelopsin-sodium induces apoptosis in human lung adenocarcinoma cell lines by promoting tubulin polymerization in vitro
}

\author{
LIJUAN ZHU ${ }^{1,2}$, BAOLAI ZHANG $^{1}$, JIANYUN LUO $^{3}$, SHUHONG DONG $^{1}$, KAIHONG ZANG $^{2}$ and YONGJIE WU ${ }^{1}$ \\ ${ }^{1}$ Department of Pharmacology, School of Basic Medical Science, Lanzhou University; \\ ${ }^{2}$ Department of Pharmacology, College of Pharmacy, Gansu University of Traditional Chinese Medicine, \\ Lanzhou, Gansu 730000; ${ }^{3}$ Department of Drug Policy and Essential Medicine, \\ Xi'an Municipal Health Commission, Xi'an, Shaanxi 710000, P.R. China
}

Received February 14, 2018; Accepted March 28, 2019

DOI: $10.3892 / \mathrm{ol} .2019 .10288$

\begin{abstract}
Previous studies have demonstrated that ampelopsin (AMP), a type of flavonoid isolated from the stems and leaves of Ampelopsis grossedentata, exhibits anti-cancer activity in various types of cancer. Conversion of AMP into its sodium salt (AMP-Na) conferred enhanced solubility and stability to it. The present study aimed to evaluate the anti-cancer activity of AMP-Na in human lung adenocarcinoma cell lines and to investigate its mechanisms of action. Cell proliferation and viability were assessed by MTT and colony formation assays, and cell migration was determined using a scratch wound healing assay. The cell cycle distribution, apoptosis rate and tubulin immunofluorescence intensity were analyzed using flow cytometry, the cell ultra-microstructure was examined using transmission electron microscopy and the accumulation of tubulin was determined using laser confocal microscopy. The results demonstrated that AMP-Na significantly inhibited the proliferation, clonogenicity and migration of human lung adenocarcinoma cells. Furthermore, AMP-Na induced SPC-A-1 cell apoptosis, and promoted tubulin polymerization. The results suggested that the underlying mechanisms of AMP-Na may involve targeting of microtubules and tubulin polymerization to subsequently disrupt mitosis and induce cell cycle arrest at the S-phase.
\end{abstract}

Correspondence to: Professor Yongjie Wu, Department of Pharmacology, School of Basic Medical Science, Lanzhou University, 199 Donggang West Road, Lanzhou, Gansu 730000, P.R. China E-mail: wuyj@1zu.edu.cn

Abbreviations: AMP, ampelopsin; CDI, coefficient of drug interaction

Key words: ampelopsin sodium, anti-tumor, apoptosis, human lung adenocarcinoma cell lines, tubulin polymerization

\section{Introduction}

Lung cancer is the most frequently diagnosed type of cancer and the leading cause of cancer-associated mortality worldwide. An estimated 1.8 million new lung cancer cases were diagnosed in 2012, which accounted for $\sim 13 \%$ of all cancer diagnoses (1). Chemotherapy is the most common treatment for cancer; however, it has severe side effects and limited efficacy. Current research focuses on developing highly efficient drugs with low toxicity for cancer treatment.

Natural products and their analogues are important sources of anti-cancer drugs that are widely used to treat patients with cancer (2). These agents include vincristine and paclitaxel (PTX). Vincristine is an anti-neoplastic agent from the vinca alkaloid family that is commonly used for acute lymphoblastic leukemia (3), whereas PTX has been isolated from the bark of Taxus brevifolia and is primarily used as a treatment for breast cancer (4). Ampelopsin (AMP), also termed dihydromyricetin, is a flavonoid (5) isolated from the tender stems and leaves of the Chinese medicinal herb Ampelopsis grossedentata (6). Previous studies have reported that AMP possesses anti-cancer activities in various cancer cell lines, including B16 melanoma cells (7), HepG2 human hepatoma cell line (8), MCF-7 and MDA-MB-231 breast cancer cells (6), PC-3 human prostate cancer cells (9) and A2780 ovarian cancer cells (10), which indicates that AMP is a promising anti-cancer agent that exhibits low toxicity (11). AMP sodium (AMP-Na) is an AMP sodium salt with higher solubility and stability compared with AMP (12). The acute systemic toxicity of AMP-Na administered intravenously was determined to be more than two times lower compared with that of AMP in a previous unpublished study; the upper tolerance dose in mice was about $2,000 \mathrm{mg} / \mathrm{kg}$ (13). However, whether the anti-cancer activity of AMP-Na is altered compared with that of AMP has remained to be fully elucidated. Our previous study has demonstrated that AMP-Na significantly inhibited the proliferation of EJ and sarcoma 180 cells in vitro and in vivo (12); the present study investigated the effects of AMP-Na, alone and in combination with other drugs, on human lung adenocarcinoma cell lines, and investigated the underlying mechanism of action. 


\section{Materials and methods}

Cell lines and reagents. The human lung adenocarcinoma SPC-A-1 and A549 cell lines were purchased from the Cell Bank of the Chinese Academy of Sciences. They were cultured in RPMI-1640 medium (Gibco; Thermo Fisher Scientific, Inc.) supplemented with $10 \%$ fetal calf serum (Sigma-Aldrich; Merck KGaA) and antibiotics (50 UI/ml penicillin $\mathrm{G}$ and $50 \mu \mathrm{g} / \mathrm{ml}$ streptomycin; Beijing Solarbio Science \& Technology Co., Ltd.) at $37^{\circ} \mathrm{C}$ in a humidified atmosphere containing $5 \% \mathrm{CO}_{2}$.

AMP-Na lyophilized powder (Guangdong Taihe Technology, Ltd., Guangdong, China) was dissolved in a mixture of phosphate buffers at $\mathrm{pH} 6.8$ and 6.5 at the final ratio of 1:1.5 [AMP-Na was alkaline $(\mathrm{pH}$ 7.6-7.8) when dissolved with $\mathrm{pH} 6.8$ buffer; therefore, the phosphate buffer at $\mathrm{pH} 6.5$ was used to adjust $\mathrm{pH}$ value] at the final concentration of was $4 \mathrm{mg} / \mathrm{ml}$. The stock solution was prepared with sterile filtered PBS (pH 6.8-7.0) and diluted with normal saline solution to the desired concentrations. MTT was purchased from Sigma-Aldrich (Merck KGaA), the Annexin V-FITC Apoptosis Detection kit was from Beyotime Institute of Biotechnology and the rat monoclonal tubulin (cat. no. ab6161) and FITC-labeled rabbit anti-mouse immunoglobulin (Ig)G antibodies (cat no. ab6730) were purchased from Abcam.

Cell viability assay. Cell viability was determined using the MTT colorimetric assay (14). Cells in the logarithmic growth phase were seeded in a 96 -well plate at $4.5 \times 10^{3}$ cells/well, incubated for $24 \mathrm{~h}$ and treated with a range of concentrations of AMP-Na $(12.5,25,50$ or $100 \mu \mathrm{g} / \mathrm{ml})$ for 48,72 or $96 \mathrm{~h}$. To investigate the effects of AMP-Na combined with different chemotherapeutic drugs, the SPC-A-1 cells were treated with AMP-Na $(50 \mu \mathrm{g} / \mathrm{ml})$ combined with carboplatin (6.25-100 $\mu \mathrm{g} / \mathrm{ml}$; Qilu Pharmaceutical Co., Ltd.), 5-fluorouracil (5-FU; 3.125-50 $\mu \mathrm{g} / \mathrm{ml}$; Jinghua Pharmaceutical Group Co., Ltd.) or PTX (3.125-50 $\mu \mathrm{g} / \mathrm{ml}$; Sichuan Shenghe Pharmaceutical Co., Ltd.) for $48 \mathrm{~h}$ prior to adding $10 \mu 1 \mathrm{MTT}$ at $37^{\circ} \mathrm{C}$ for $4 \mathrm{~h}$. The reaction product, formazan, was dissolved using $100 \mu \mathrm{l}$ $10 \%$ SDS (14) and the absorbance at $570 \mathrm{~nm}$ was read using an EL800 microplate reader (Bio-Tek Instruments, Inc.). The experiments were performed in triplicate. Cell viability was calculated as follows: Cell viability $(\%)=\mathrm{A}_{\text {treated }} / \mathrm{A}_{\text {control }} \times 100 \%$, where $\mathrm{A}$ is absorbance. The coefficient of drug interaction (CDI) was calculated as follows: $\mathrm{CDI}=\mathrm{AB} /(\mathrm{A} \times \mathrm{B})$, where $\mathrm{AB}$ is the absorbance ratio of the combination groups to the control group, and A or B are the absorbance ratios of the single agent groups to the control group. A CDI value $<1,=1$ or $>1$ was considered to indicate that drugs were synergistic, additive or antagonistic, respectively (15).

Colony formation assay. The SPC-A-1 and A549 cells were trypsinized to obtain single-cell suspensions and seeded into 6-mm incubation plates at a density of 250 cells/well. Cells were treated with AMP-Na ( 25 or $50 \mu \mathrm{g} / \mathrm{ml})$, cultured for 15 days and subsequently fixed with methanol and glacial acetic acid (ratio, 7:1) for $25 \mathrm{~min}$ at $25^{\circ} \mathrm{C}$ and stained with $0.1 \%$ crystal violet for $25 \mathrm{~min}$ at $25^{\circ} \mathrm{C}$. The colonies that contained $>50$ cells were counted using Image-pro plus 6.0 (Media Cybernetics, Inc.).
Scratch wound healing assay. A scratch wound healing assay was used to evaluate the migratory ability of SPC-A-1 and A549 cells. Cells $\left(5 \times 10^{5} / \mathrm{ml}\right)$ were cultured in 12-well plates for $24 \mathrm{~h}$. Straight scratches of equal width were made in the monolayer of cells using a $200 \mu 1$ pipette tip, and the monolayers were washed twice with PBS to remove debris. Following incubation with $50 \mu \mathrm{g} / \mathrm{ml}$ AMP-Na for $24 \mathrm{~h}$, images were captured using a CKX41 inverted light microscope (Olympus Corporation). And the gap width was measured using Image-pro plus 6.0.

Cell apoptosis analysis by flow cytometry. Following culture in 6-well plates at $2 \times 10^{5}$ cells/well for $24 \mathrm{~h}$, SPC-A-1 cells were treated with $100 \mu \mathrm{g} / \mathrm{ml}$ AMP-Na for $48 \mathrm{~h}$, collected in $1.5-\mathrm{ml}$ centrifuge tubes, washed twice with cold PBS and re-suspended in binding buffer. A total of $2 \mu 1$ Annexin V-FITC and propidium iodide were added separately, followed by incubation in the dark for 15 min and analysis using a flow cytometer.

Cell cycle distribution analysis by flow cytometry. SPC-A-1 cells were seeded at $5 \times 10^{5}$ cells/flask in a 100 -ml culture flask for $24 \mathrm{~h}$, treated with $100 \mu \mathrm{g} / \mathrm{ml}$ AMP-Na for $48 \mathrm{~h}$, harvested and fixed in ice-cold $75 \%$ ethanol at $-20^{\circ} \mathrm{C}$ overnight. Following washing with PBS, cells were fixed with $500 \mu \mathrm{l}$ staining solution containing propidium iodide $(50 \mu \mathrm{g} / \mathrm{ml})$ and RNase (50 $\mu \mathrm{g} / \mathrm{ml}$; Jiangsu KeyGEN BioTECH Corp., Ltd.) and incubated for $30 \mathrm{~min}$ in the dark at room temperature. Flow cytometric analysis was performed and the cell proportion in each phase was calculated using a Cell FIT DNA Analysis system (BD Biosciences).

Ultra-microstructure analysis. SPC-A-1 cells were seeded at $5 \times 10^{5}$ cells/flask in a 100-ml culture flask for $24 \mathrm{~h}$. Following treatment with $100 \mu \mathrm{g} / \mathrm{ml}$ AMP-Na for $48 \mathrm{~h}$, cells were harvested, fixed with $2.5 \%$ glutaraldehyde for $2 \mathrm{~h}$ at $4^{\circ} \mathrm{C}$, washed with PBS three times, fixed in $1 \%$ osmium tetroxide for $1 \mathrm{~h}$ at $4^{\circ} \mathrm{C}$, dehydrated in graded ethanol, and embedded in araldite. The ultrathin sections of cells $(50-70 \mathrm{~nm})$ were prepared and stained with $1 \%(\mathrm{w} / \mathrm{v})$ uranyl acetate and lead citrate. Transmission electron microscopy (TEM; JEOL, Ltd.) was used to analyze the cell ultra-microstructure.

Immunofluorescence intensity analysis. Following treatment with $1 \mathrm{ml}$ AMP-Na at a range of concentrations $(12.5,25$, 50 and $100 \mu \mathrm{g} / \mathrm{ml}$ ) for $48 \mathrm{~h}$, SPC-A-1 cells were collected, washed twice with PBS, fixed with $3.7 \%$ paraformaldehyde for $15 \mathrm{~min}$ at $4^{\circ} \mathrm{C}$, and treated with $0.3 \%$ Triton X-100 for $10 \mathrm{~min}$ on ice. Cells were incubated with the primary rat monoclonal anti-tubulin antibody (1:400) on ice for $40 \mathrm{~min}$, washed twice with cold PBS, stained with the FITC-labeled rabbit anti-rat IgG antibody (1:200) on ice for $40 \mathrm{~min}$ and post-fixed with $1 \%$ paraformaldehyde at $4^{\circ} \mathrm{C}$ for at least 30 min. Cells were washed again, re-suspended in PBS and analyzed by flow cytometry.

Laser confocal microscopic analysis. SPC-A-1 cells were seeded in $100-\mathrm{ml}$ culture flasks $\left(5 \times 10^{5}\right.$ cells/flask $)$. Polylysine-coated glass coverslips were embedded in the flasks for $24 \mathrm{~h}$, followed by exposure to AMP-Na (25, 50 or 
A

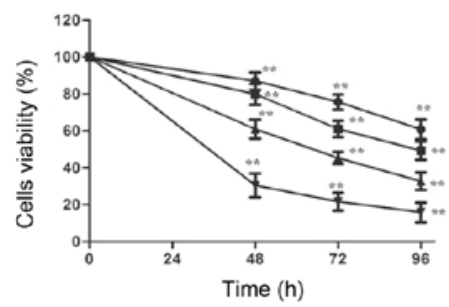

C

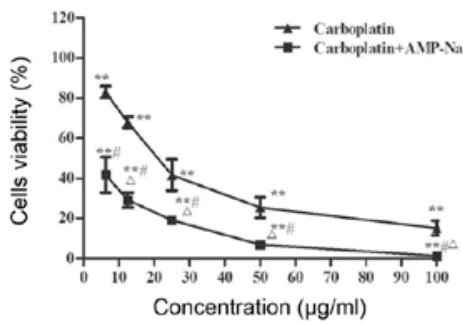

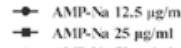

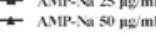

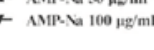

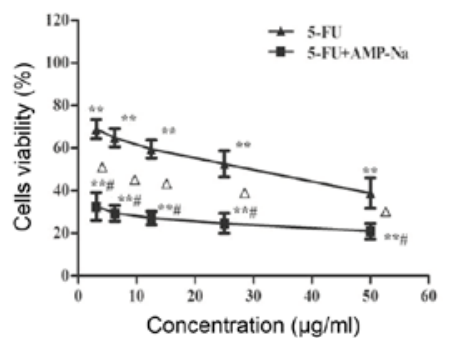

B

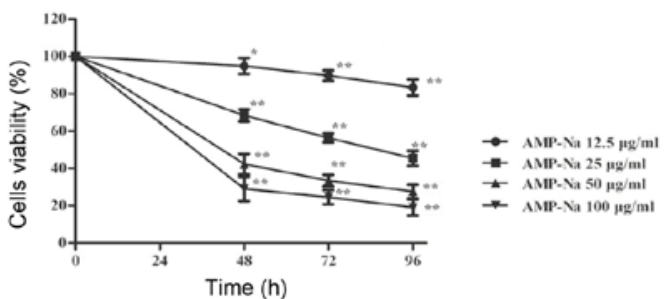

E

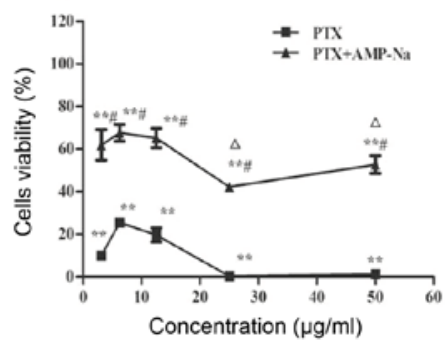

Figure 1. AMP-Na decreases lung cancer cell proliferation in vitro. The effect of AMP-Na on (A) SPC-A-1 and (B) A549 cells was assessed using an MTT assay following 48, 72 and $96 \mathrm{~h}$ of incubation. The effects of AMP-Na (50 $\mu \mathrm{g} / \mathrm{ml})$ combined with (C) carboplatin, (D) 5-FU and (E) PTX on SPC-A-1 cells were measured by an MTT assay after $48 \mathrm{~h}$ of incubation. Three individual experiments were performed. ${ }^{*} \mathrm{P}<0.05$ and ${ }^{* *} \mathrm{P}<0.01$ vs. control group; ${ }^{\#} \mathrm{P}<0.01$ vs. carboplatin, 5-FU or PTX group, respectively; ${ }^{\Delta} \mathrm{P}<0.01$ vs. AMP-Na group. 5-FU, 5-fluorouracil; AMP-Na, ampelopsin-sodium; PTX, paclitaxel.

$100 \mu \mathrm{g} / \mathrm{ml}$ ) for $48 \mathrm{~h}$. Coverslips were collected, washed with PBS and fixed with $3.7 \%$ paraformaldehyde for $15 \mathrm{~min}$ at room temperature. Cells were permeabilized with $0.3 \%$ Triton X-100 for $5 \mathrm{~min}$ on ice, washed three times with PBS and incubated with the primary rat monoclonal anti-tubulin antibody (1:400) in a sealed wet incubation chamber at $37^{\circ} \mathrm{C}$ for $1 \mathrm{~h}$. Coverslips were washed three times with PBS for 5 min, stained with the FITC-labeled rabbit anti-mouse IgG antibody (1:100) in a sealed wet box at $37^{\circ} \mathrm{C}$ for $1 \mathrm{~h}$, and analyzed by laser confocal microscopy (Leica TCSSP2; Leica Microsystems Heidelberg $\mathrm{GmbH})$.

Statistical analysis. All experiments were repeated at least three times. Statistical analysis was performed using SPSS 17.0 (SPSS, Inc.). Differences between two groups were analyzed using a Student's t-test. For comparison of multiple groups, one-way analysis of variance followed by Dunnett's post hoc test was used. Values are expressed as the mean \pm standard deviation. $\mathrm{P}<0.05$ was considered to indicate a statistically significant difference.

\section{Results}

AMP-Na inhibits lung cancer cell proliferation. Compared with control group, AMP-Na significantly reduced the proliferation of SPC-A-1 and A549 cells in a time- and dose-dependent manner, when used at $12.5-100 \mu \mathrm{g} / \mathrm{ml}$ for 48 , 72 or $96 \mathrm{~h}$ (Fig. 1A and B). In addition, combined treatment with AMP-Na $(50 \mu \mathrm{g} / \mathrm{ml})$ and carboplatin or $5-\mathrm{FU}$ inhibited cell viability synergistically across a wide concentration range ( $\mathrm{CDI}<1$; Fig. 1C and D), whereas the combination with PTX displayed potential antagonism as cell viability was significantly enhanced at all concentrations in the PTX + AMP-Na group compared with the PTX only group (CDI $>1$; Fig. 1E). These results suggested that AMP-Na and PTX may have similar targets.
AMP-Na inhibits the colony formation of lung cancer cells. Following 15 days in culture, a significant decline in the number and size of the colonies was detected in the SPC-A-1 and A549 cells treated with AMP-Na $(25$ and $50 \mu \mathrm{g} / \mathrm{ml})$. These results suggested that AMP-Na markedly suppressed the colony formation capabilities of human lung adenocarcinoma cell lines in vitro (Fig. 2).

AMP-Na inhibits the migration of lung cancer cells. A wound healing assay was used to evaluate cell migration. The SPC-A-1 and A549 cell lines were treated with AMP-Na $(100 \mu \mathrm{g} / \mathrm{ml})$ for $24 \mathrm{~h}$. The results demonstrated that scratch healing was significantly reduced in the presence of AMP-Na and cells treated with AMP-Na exhibited a significantly lower migratory ability compared with those in the control group $(\mathrm{P}<0.01$; Fig. 3).

AMP-Na induces apoptosis and cell cycle arrest in SPC-A-1 cells. The apoptotic rate in the $100 \mu \mathrm{g} / \mathrm{ml}$ AMP-Na-treated group was higher compared with that in the control group $(14.71 \pm 1.10$ vs. $4.31 \pm 0.56 \%$; $\mathrm{P}<0.01$; Fig. $4 \mathrm{~A})$. In addition, following treatment with $100 \mu \mathrm{g} / \mathrm{ml}$ AMP-Na for $48 \mathrm{~h}$, flow cytometry revealed a peak of cells in sub-G1 phase (Fig. 4B). In addition, the number of cells in S-phase was increased in the AMP-Na-treated group compared with that in the control group $(\mathrm{P}<0.01$; Fig. $4 \mathrm{~B})$, whereas the number of cells in $\mathrm{G}_{2} / \mathrm{M}$-phase and G1-phase were significantly decreased $(\mathrm{P}<0.05$; Fig. 4B).

Effect of AMP-Na on SPC-A-1 cell ultra-microstructure. The cell ultra-microstructure was examined by TEM. The results demonstrated that cells in the control group had abundant organelles, intact and distinct cellular ultra-structures and well-distributed chromatin (Fig. 5A). Of note, treatment with AMP-Na $(100 \mu \mathrm{g} / \mathrm{ml})$ induced a cytoplasm vacuolization and chromatin margination (Fig. 5B). In addition, nucleus 

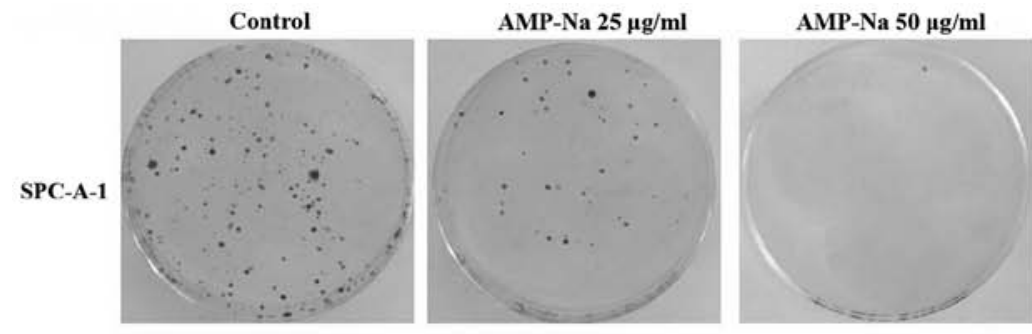

A549
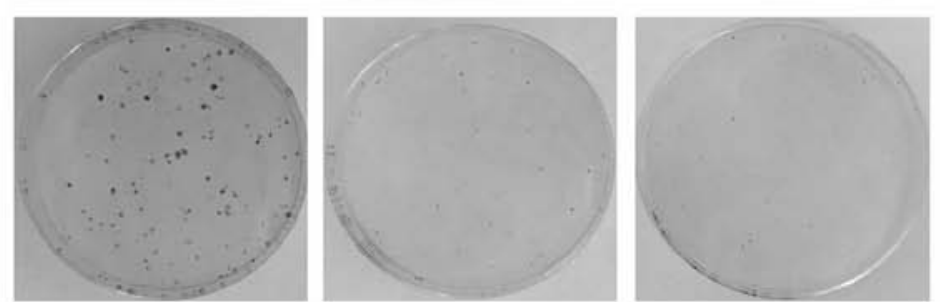

Figure 2. Effect of AMP-Na on lung cancer cell colony formation. ${ }^{* *} \mathrm{P}<0.01$ vs. control group. AMP-Na, ampelopsin-sodium.
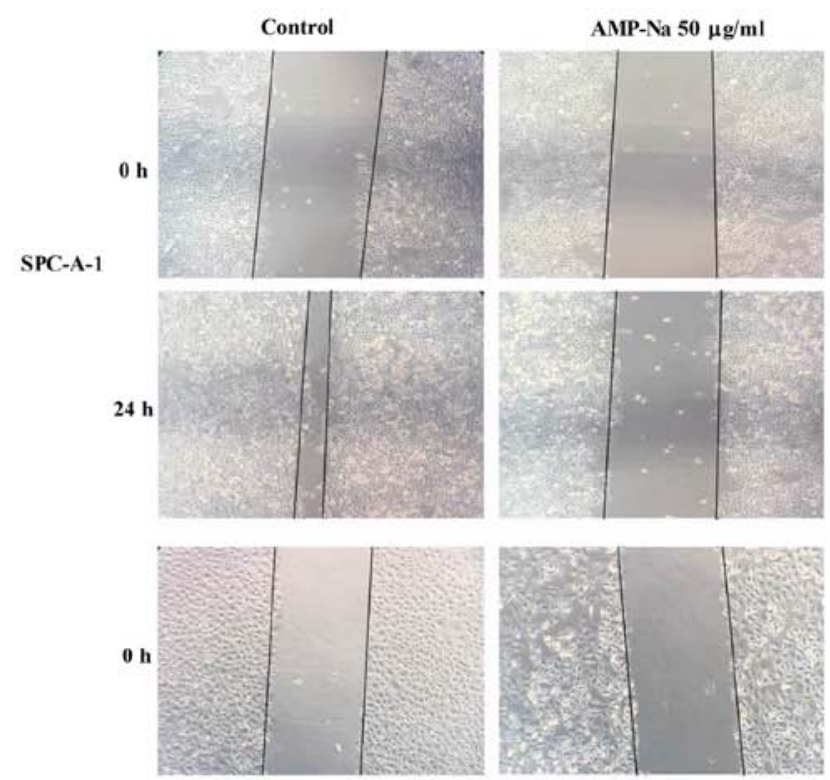

A549
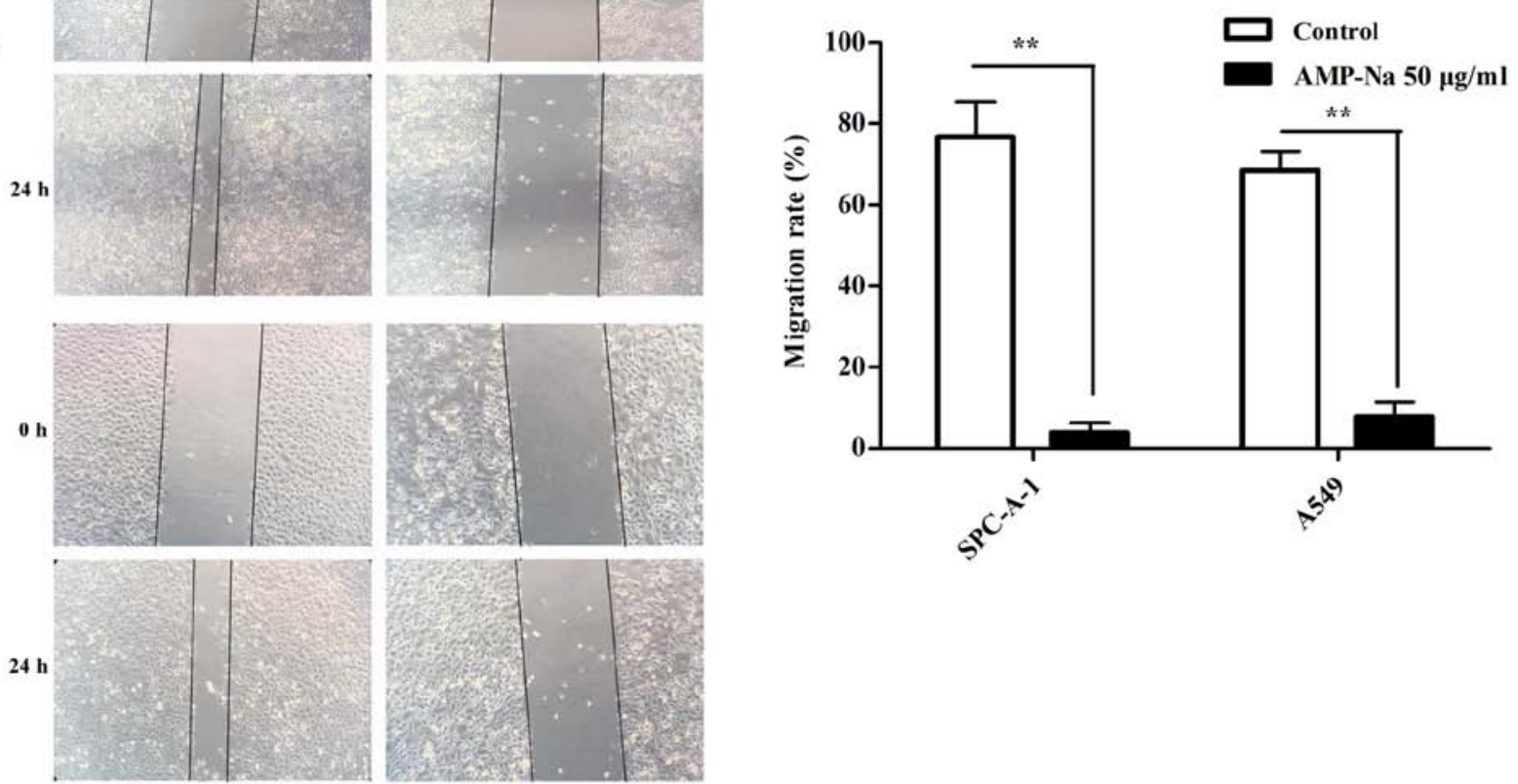

Figure 3. Effect of AMP-Na on lung cancer cell migration. The effect of AMP-Na on lung cancer cell migration was examined by a wound healing assay. Representative digital images were captured at 0 and $24 \mathrm{~h}$. Magnification, $\mathrm{x} 10 .{ }^{* *} \mathrm{P}<0.01 \mathrm{vs}$. control group. AMP-Na, ampelopsin-sodium.

deformation, nuclear membrane shrinkage and mitochondrial swelling were observed in the AMP-Na-treated group.

Effect of AMP-Na on microtubulin immunofluorescence. Flow cytometric analysis was used to assess the tubulin mean fluorescence intensity (MFI) in the different groups (Fig. 6). In the control group, the MFI was $2.08 \pm 0.13$ following 48-h culture (Fig. 6A and F), whereas in the $12.5 \mu \mathrm{g} / \mathrm{ml}$ AMP-Na-treated group it was $2.28 \pm 0.04$ (Fig. 6B and F). No significant difference was observed in the MFI between these two groups. The tubulin MFI in cells treated with 25, 50 and $100 \mu \mathrm{g} / \mathrm{ml}$ AMP-Na was $2.96 \pm 0.18,3.62 \pm 0.29$ and $8.37 \pm 0.03$, respectively, which was significantly different compared with that in the control group $(\mathrm{P}<0.01$; Fig. $6 \mathrm{C}-\mathrm{F})$. These results suggested that AMP-Na may increase the tubulin MFI in a dose-dependent manner.

Effect of AMP-Na on tubulin polymerization in SPC-A-1 cells. Microtubule morphology in cells treated with AMP-Na was examined by confocal microscopy. Untreated cells exhibited a normal microtubule network, which radiated from the center to the cell periphery (Fig. 7A). Treatment with $25 \mu \mathrm{g} / \mathrm{ml}$ AMP-Na induced a slight tubulin accumulation (Fig. 7B), whereas treatment with $50 \mu \mathrm{g} / \mathrm{ml}$ AMP-Na caused an abnormal aggregation of 

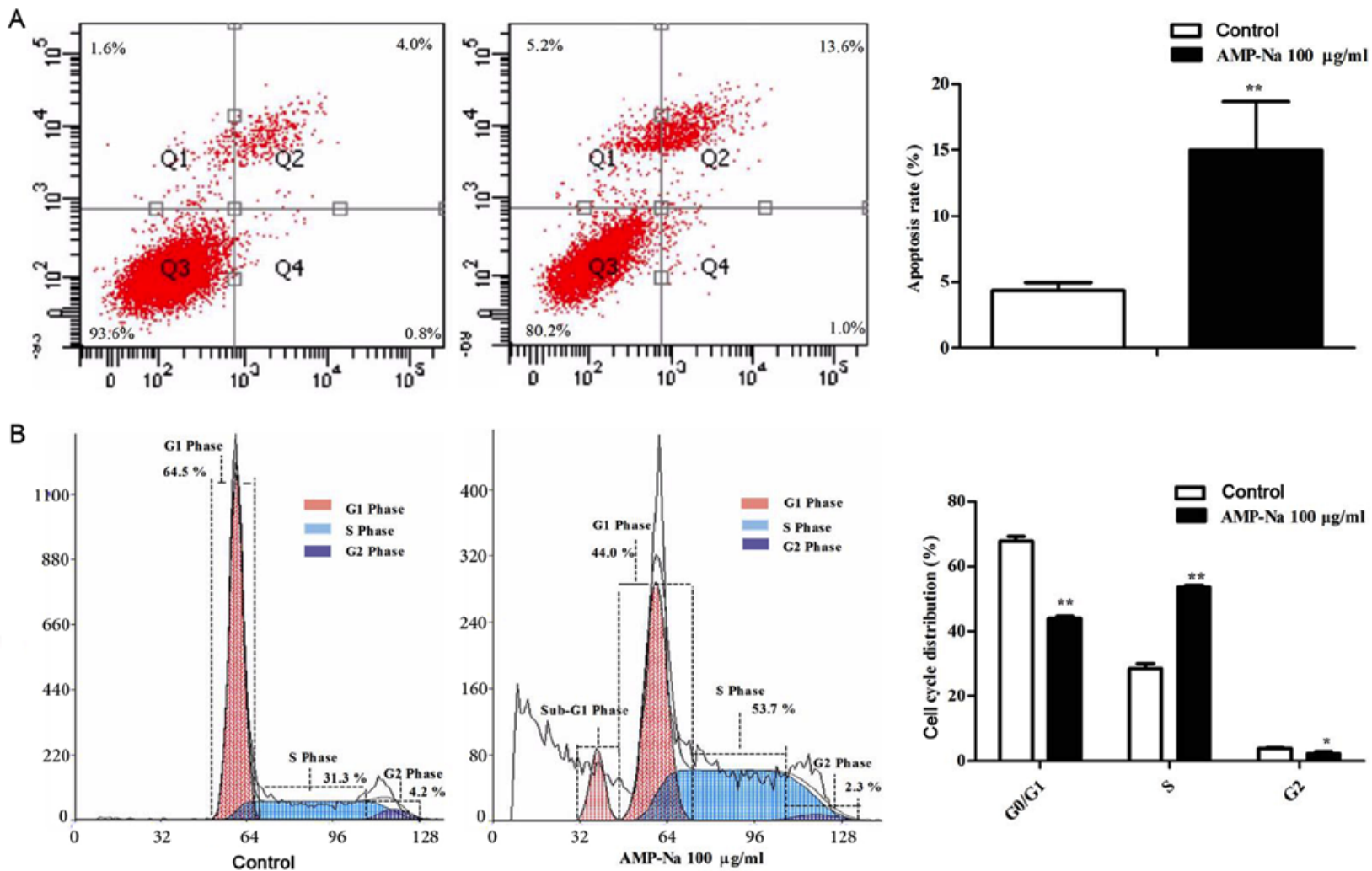

Figure 4. Effect of AMP-Na on apoptosis and cell cycle arrest in SPC-A-1 cells assessed by flow cytometry. (A) Early and late apoptotic rates and (B) cell cycle distribution in the control and AMP-Na-treated groups. ${ }^{*} \mathrm{P}<0.05$ and ${ }^{* *} \mathrm{P}<0.01$ vs. control group. AMP-Na, ampelopsin-sodium; PI, propidium iodide.

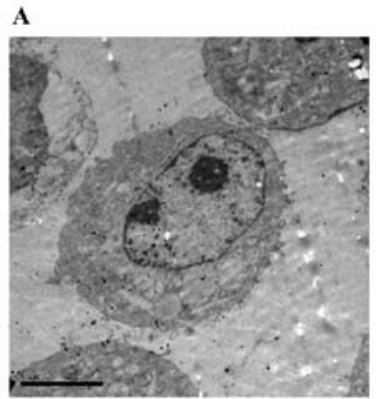

B

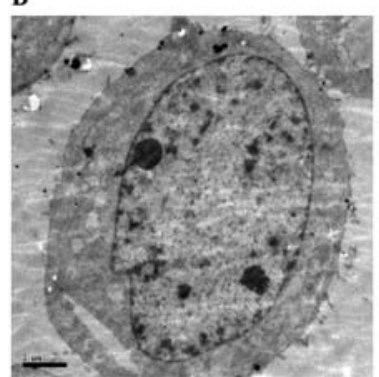

C

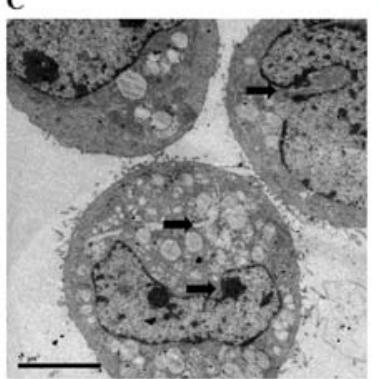

D

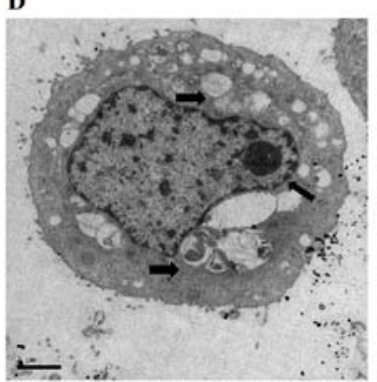

Figure 5. Effect of AMP-Na treatment on the ultra-microstructure of SPC-A-1 cells. Following treatment, cells were fixed and stained with $1 \%$ (w/v) uranyl acetate to assess cellular morphology using transmission electron microscopy. (A and B) Cells of the control group and (C and D) cell of the group treated with AMP-Na $(100 \mu \mathrm{g} / \mathrm{ml})$ for $48 \mathrm{~h}$, arrows indicate the morphological characteristics of apoptosis. Scale bars, $5 \mu \mathrm{m}$ (A and C) or $2 \mu \mathrm{m}$ (B and D). AMP-Na, ampelopsin-sodium.

tubulin (Fig. 7C). In addition, treatment with $100 \mu \mathrm{g} / \mathrm{ml}$ AMP-Na caused microtubule agglomeration in the cytoplasm (Fig. 7D).

\section{Discussion}

Tumorigenesis is a complex process caused by dysregulated cell proliferation, cell differentiation and cell death, which may be caused by various factors, including genetic alterations and changes in the intracellular environment (16-18). In the present study, an MTT assay demonstrated that AMP-Na was able to inhibit the proliferation of lung cancer cell lines in a time- and dose-dependent manner. Furthermore, treatment with 25 and $50 \mu \mathrm{g} / \mathrm{ml}$ AMP-Na significantly inhibited colony formation by SPC-A-1 and A549 cells. In addition, the wound healing assay demonstrated that AMP-Na reduced the migratory/metastatic ability of lung cancer cells. In order to further investigate the anti-tumor effects of AMP-Na, cell apoptosis was determined using flow cytometry and TEM. The results of the flow cytometric analysis demonstrated that following treatment with AMP-Na $(100 \mu \mathrm{g} / \mathrm{ml})$ for $48 \mathrm{~h}$, the SPC-A-1 apoptotic rate was higher compared with that in the control group (14.71 \pm 1.10 vs. $4.31 \pm 0.56 \%$; $\mathrm{P}<0.01)$. In addition, TEM revealed morphological characteristics of apoptosis $(19,20)$, including cytoplasm vacuolization, chromatin margination, nuclear membrane shrinkage and mitochondrial swelling in AMP-Na-treated cells.

In the present study, AMP-Na combined with PTX displayed an antagonistic effect, which suggested that AMP-Na and PTX may have similar molecular targets. It has been reported that PTX targets microtubules, and it is known that microtubule-targeting agents disrupting normal microtubule dynamics lead to cancer cell apoptosis (21). Therefore, microtubules represent a crucial target for anti-cancer 

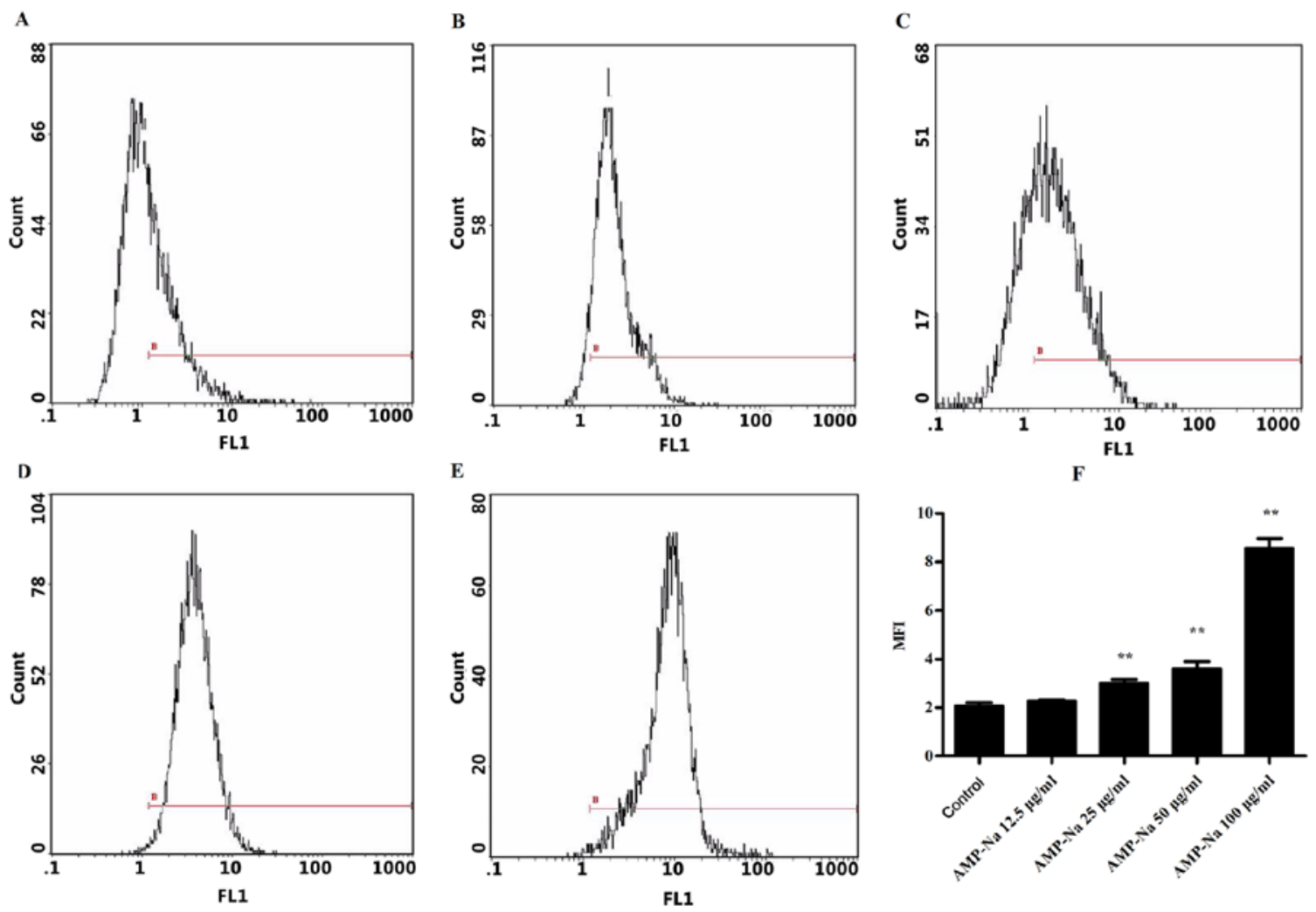

Figure 6. Effect of AMP-Na on microtubulin immunofluorescence. (A) Control cells and cells treated with (B) 12.5 , (C) 25 and (D) 50 or (E) $100 \mu \mathrm{g} / \mathrm{ml}$ AMP-Na were fixed, incubated with the primary rat monoclonal tubulin antibody, stained with the FITC-labeled rabbit anti-mouse immunoglobulin G antibody, re-suspended in PBS and analyzed by flow cytometry. A mouse IgG1 isotype control was used for making gates, and the PTX control was used as a positive control (F) MFI of cells treated with AMP-Na at different concentrations. Three individual experiments were performed. ${ }^{* *} \mathrm{P}<0.01$ vs. control. AMP-Na, ampelopsin-sodium; MFI, mean fluorescence intensity.
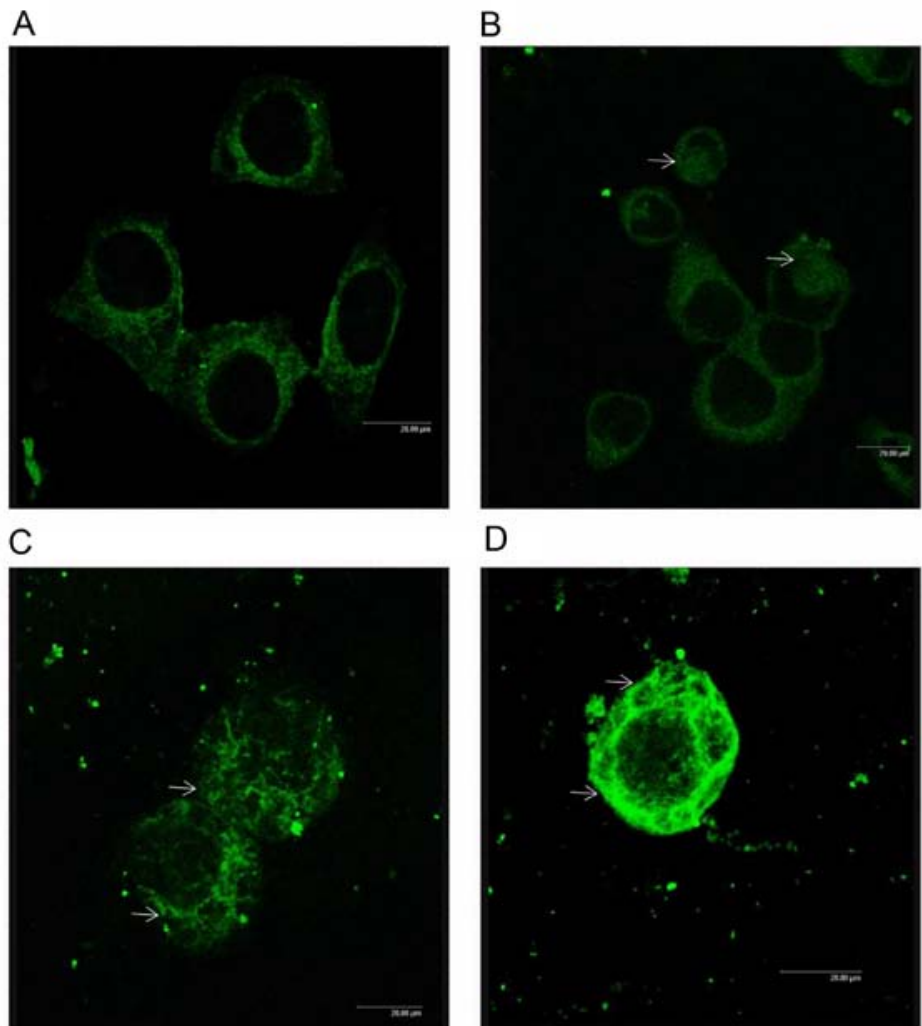

\section{D}

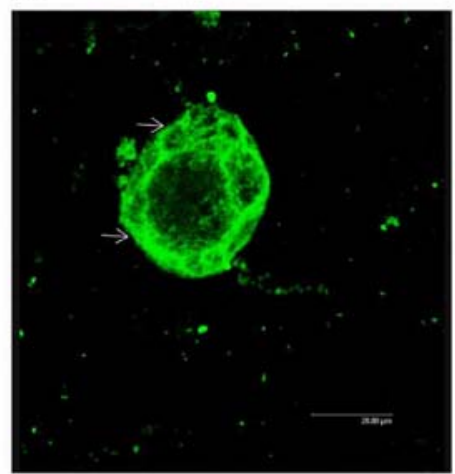

Figure 7. Effect of AMP-Na on tubulin aggregation. (A) Control cells and cells treated with (B) 25, (C) 50 or (D) $100 \mu \mathrm{g} / \mathrm{ml}$ AMP-Na were fixed, incubated with primary rat monoclonal tubulin antibody, stained with fluorescein isothiocyanate-labeled rabbit anti-mouse immunoglobulin $\mathrm{G}$ antibody, re-suspended in PBS and analyzed using a laser confocal microscope (scale bar, $20 \mu \mathrm{m}$ ). AMP-Na, ampelopsin-sodium. 
therapy (22). Microtubules serve a crucial role in cell division and in the maintenance of cell shape (23), particularly in the dynamic processes of tubulin polymerization and depolymerization during replication and division (24). Numerous anti-cancer agents exert their effects through disturbance of microtubule dynamics, which leads to dysregulation of mitotic spindles and causes mitotic arrest of cancer cells. For instance, PTX binds to the microtubule network, stabilizes microtubule bundles and impairs cellular mitosis in various types of cancer cell $(25,26)$. By contrast, vinca alkaloids inhibit microtubule polymerization, which results in mitotic block and apoptotic cell death (27). The results of the present study demonstrated that AMP-Na increased tubulin fluorescence intensity in a dose-dependent manner. Confocal microscopy revealed that untreated cells exhibited a normal microtubule network radiating from the center to the cell periphery, whereas AMP-Na-treated cells exhibited abnormally distributed microtubules with massive accumulation in the cell periphery or surrounding the nuclei. The degree of aggregation increased in a concentration-dependent manner. In the high-concentration AMP-Na $(100 \mu \mathrm{g} / \mathrm{ml})$ group in particular, the fluorescence intensity was increased and the extensive aggregation of tubulin could be seen around the nucleus

A crucial characteristic of traditional anti-cancer agents is the ability to induce cell cycle arrest (28). Anti-tumor tubulin ligands disturb microtubule dynamics during the $\mathrm{G}_{2} / \mathrm{M}$ phase $(29,30)$; however, due to the mode of interaction between microtubules and proteins and/or the effectiveness of spindle assembly checkpoints, cell cycle arrest at $\mathrm{G}_{1}-$ or $\mathrm{S}$-phase has also been reported in various types of cancer cell (31). For instance, Davis et al (32) revealed that haloacetamido benzoyl ethyl esters may target tubulin and cause a block of the $G_{1} / S$ cell cycle transition in cancer cells. In the present study, AMP-Na induced cell cycle arrest in the $\mathrm{S}$-phase, and a subsequent decrease in the G1 or G2-phase was observed in SPC-A-1 cells treated with AMP-Na, which suggested that tubulin has multiple functions and mitosis may not be the specific target for anti-tubulin agents (33). Early reports also indicated that microtubule-damaging agents effectively inhibit cell cycle progression and induce apoptosis without inducing mitotic arrest (34); the results of the present study were consistent with these studies. Tubulin is associated with the downstream apoptotic system, as tubulin ligands induce bcl-2 phosphorylation by raf-1 kinase, which results in apoptosis (35). In addition, the P53-mediated G1/S checkpoint is associated with S-phase arrest (32). Tubulin-targeting agents have been previously demonstrated to arrest the cell cycle in S-phase $(32,34,36)$ and the S-phase arresting agents have been evaluated for their potential clinical utility; for example, $\beta$-lapachone induced $S$-phase arrest (37) and is currently undergoing phase I clinical trials for the treatment of solid tumors (https://clinicaltrials.gov; NCT01502800). The present study suggested that AMP-Na may interfere with the cell cycle by targeting microtubules, promoting tubulin polymerization and eventually inducing apoptosis. AMP-Na may have considerable clinical potential, for example, AMP-Na combined with a G2/M-phase-arresting drug may enhance the clearance of cancer cells at different stages of cell cycle.

\section{Acknowledgements}

Not applicable.

\section{Funding}

No funding was received.

\section{Availability of data and materials}

All data generated or analyzed during this study are included in this published article.

\section{Authors' contributions}

LZ and YW conceived and designed the study. LZ and BZ performed the experiments. LZ and JL analyzed the data. KZ and SD contributed to the acquisition of data and drafting the manuscript. All authors read and approved the final manuscript.

\section{Ethics approval and consent to participate}

Not applicable.

\section{Patient's consent for publication}

Not applicable.

\section{Competing interests}

The authors declare that they have no competing interests.

\section{References}

1. Torre LA, Bray F, Siegel RL, Ferlay J, Lortet-Tieulent J and Jemal A: Global cancer statistics, 2012. CA Cancer J Clin 65: 87-108, 2015

2. Hua F, Shang S and Hu ZW: Seeking new anti-cancer agents from autophagy-regulating natural products. J Asian Nat Prod Res 19: 305-313, 2017.

3. Nazir HF, AlFutaisi A, Zacharia M, Elshinawy M, Mevada ST, Alrawas A, Khater D, Jaju D and Wali Y: Vincristine-induced neuropathy in pediatric patients with acute lymphoblastic leukemia in Oman: Frequent autonomic and more severe cranial nerve involvement. Pediatr Blood Cancer 64: 2017.

4. Khongkow M, Olmos Y, Gong C, Gomes AR, Monteiro LJ, Yague E, Cavaco TB, Khongkow P, Man EP, Laohasinnarong S, et al: SIRT6 modulates paclitaxel and epirubicin resistance and survival in breast cancer. Carcinogenesis 34: 1476-1486, 2013

5. Chen XM, Xie XB, Zhao Q, Wang F, Bai Y, Yin JQ, Jiang H, Xie XL, Jia Q and Huang G: Ampelopsin induces apoptosis by regulating multiple $\mathrm{c}-\mathrm{Myc} / \mathrm{S}$-phase kinase-associated protein 2/F-box and WD repeat-containing protein 7/histone deacetylase 2 pathways in human lung adenocarcinoma cells. Mol Med Rep 11: 105-112, 2015.

6. Zhou Y, Shu F, Liang X, Chang H, Shi L, Peng X, Zhu J and Mi M: Ampelopsin induces cell growth inhibition and apoptosis in breast cancer cells through ROS generation and endoplasmic reticulum stress pathway. PLoS One 9: e89021, 2014.

7. Zheng HQ and Liu DY: Anti-invasive and anti-metastatic effect of ampelopsin on melanoma. Ai Zheng 22: 363-367, 2003 (In Chinese).

8. Qi S, Kou X, Lv J, Qi Z and Yan L: Ampelopsin induces apoptosis in HepG2 human hepatoma cell line through extrinsic and intrinsic pathways: Involvement of P38 and ERK. Environ Toxicol Pharmacol 40: 847-854, 2015. 
9. Ni F, Gong Y, Li L, Abdolmaleky HM and Zhou JR: Flavonoid ampelopsin inhibits the growth and metastasis of prostate cancer in vitro and in mice. PLoS One 7: e38802, 2012.

10. Liu T, Liu P, Ding F, Yu N, Li S, Wang S, Zhang X, Sun X, Chen Y, Wang F, et al: Ampelopsin reduces the migration and invasion of ovarian cancer cells via inhibition of epithelial-to-mesenchymal transition. Oncol Rep 33: 861-867, 2015.

11. Ruan LP, Yu BY, Fu GM and Zhu DN: Improving the solubility of ampelopsin by solid dispersions and inclusion complexes. J Pharm Biomed Anal 38: 457-464, 2005.

12. Zhang B, Dong S, Cen X, Wang X, Liu X, Zhang H, Zhao X and $\mathrm{Wu}$ Y: Ampelopsin sodium exhibits antitumor effects against bladder carcinoma in orthotopic xenograft models. Anticancer Drugs 23: 590-596, 2012.

13. Qin H: Study on preparation of high-water-soluble ampelopsin sodium and its anti-tumor effects (unpublished $\mathrm{PhD}$ thesis). Lanzhou University, 2006.

14. Tada H, Shiho O, Kuroshima K, Koyama M and Tsukamoto K An improved colorimetic assay for interleukin 2. J Immunol Methods 93: 157-165, 1986.

15. Cao SS and Zhen YS: Potentiation of antimetabolite antitumor activity in vivo by dipyridamole and amphotericin B. Cancer Chemother Pharmacol 24: 181-186, 1989.

16. Fernandez V, Hartmann E, Ott G, Campo E and Rosenwald A: Pathogenesis of mantle-cell lymphoma: All oncogenic roads lead to dysregulation of cell cycle and DNA damage response pathways. J Clin Oncol 23: 6364-6369, 2005.

17. Bisbis B, Delmas F, Joubès J, Sicard A, Hernould M, Inzé D, Mouras A and Chevalier C: Cyclin-dependent kinase (CDK) inhibitors regulate the CDK-cyclin complex activities in endoreduplicating cells of developing tomato fruit. J Biol Chem 281: 7374-7383, 2006.

18. Ford HL and Pardee AB: Cancer and the cell cycle. J Cell Biochem 32-33 (Suppl): 166-172, 1999.

19. Nagasaka A, Kawane $K$, Yoshida $H$ and Nagata $S$ : Apaf-1-independent programmed cell death in mouse development. Cell Death Differ 17: 931-941, 2010.

20. Burgess DJ: Apoptosis: Refined and lethal. Nat Rev Cancer 13: 79, 2013.

21. Annamalai P, Thayman M, Rajan S, Raman LS, Ramasubbu S and Perumal P: Ethyl acetate extract from marine sponge Hyattella cribriformis exhibit potent anticancer activity by promoting tubulin polymerization as evidenced mitotic arrest and induction of apoptosis. Pharmacogn Mag 11: 345-355, 2015.

22. Marko D, Kemény M, Bernady E, Habermeyer M, Weyand U, Meiers S, Frank $\mathrm{O}$ and Hofmann T: Studies on the inhibition of tumor cell growth and microtubule assembly by 3-hydroxy-4-[(E)-(2-furyl)methylidene]methyl-3-cyclopentene1,2-dione, an intensively coloured Maillard reaction product. Food Chem Toxicol 40: 9-18, 2002.

23. Tong C, Fan HY, Chen DY, Song XF, Schatten H and Sun QY: Effects of MEK inhibitor U0126 on meiotic progression in mouse oocytes: Microtuble organization, asymmetric division and metaphase II arrest. Cell Res 13: 375-383, 2003.
24. Wilson L and Jordan MA: Microtubule dynamics-taking aim at a moving target. Chem Biol 2: 569-573, 1995.

25. Maushagen R, Reers S, Pfannerstill AC, Hahlbrock A, Stauber R, Rahmanzadeh R, Rades D, Pries R and Wollenberg B: Effects of paclitaxel on permanent head and neck squamous cell carcinoma cell lines and identification of anti-apoptotic caspase 9b. J Cancer Res Clin Oncol 142: 1261-1271, 2016.

26. Luo Y, Ji X, Liu J, Li Z, Wang W, Chen W, Wang J, Liu Q and Zhang X: Moderate intensity static magnetic fields affect mitotic spindles and increase the antitumor efficacy of 5-FU and taxol. Bioelectrochemistry 109: 31-40, 2016.

27. Chiu WH, Luo SJ, Chen CL, Cheng JH, Hsieh CY, Wang CY, Huang WC, Su WC and Lin CF: Vinca alkaloids cause aberrant ROS-mediated JNK activation, Mcl-1 downregulation, DNA damage, mitochondrial dysfunction, and apoptosis in lung adenocarcinoma cells. Biochem Pharmacol 83: 1159-1171, 2012.

28. Sun B, Wingate H, Swisher SG, Keyomarsi K and Hunt KK: Absence of $\mathrm{pRb}$ facilitates E2F1-induced apoptosis in breast cancer cells. Cell Cycle 9: 1122-1130, 2010.

29. Gamell C, Schofield AV, Suryadinata R, Sarcevic B and Bernard O: LIMK2 mediates resistance to chemotherapeutic drugs in neuroblastoma cells through regulation of drug-induced cell cycle arrest. PLoS One 8: e72850, 2013.

30. Wang X, Tanaka M, Krstin S, Peixoto HS and Wink M: The interference of selected cytotoxic alkaloids with the cytoskeleton: An insight into their modes of action. Molecules 21: E906, 2016.

31. Giannakakou P, Sackett D and Fojo T: Tubulin/microtubules: Still a promising target for new chemotherapeutic agents. J Natl Cancer Inst 92: 182-183, 2000.

32. Davis A, Jiang JD, Middleton KM, Wang Y, Weisz I, Ling YH and Bekesi JG: Novel suicide ligands of tubulin arrest cancer cells in S-phase. Neoplasia 1: 498-507, 1999.

33. Komlodi-Pasztor E, Sackett D, Wilkerson J and Fojo T: Mitosis is not a key target of microtuble agents in patient tumors. Nat Rev Clin Oncol 8: 244-250, 2011.

34. Cheriyamundath S, Mahaddalkar T, Kantevari S and Lopus M: Induction of acetylation and bundling of cellular microtubules by 9-(4-vinylphenyl) noscapine elicits S-phase arrest in MDA-MB-231 cells. Biomed Pharmacotherapy 86: 74-80, 2017.

35. Blaqosklonny MV, Ginanakakou P, el-Deiry WS, Kingston DG, Higgs PI, Neckers L and Foji T: Raf-1/bcl-2 phosphorylatin: A step from microtuble damage to cell death. Cancer Res 57: 130-135, 1997.

36. Mahaddalkar T, Mehta S, Cheriyamundath S, Muthurajan H and Lopus M: Tryptone-stabilized gold nanoparticles target tubulin and inhibit cell viability by inducing an unusual form of cell cycle arrest. Exp Cell Res 360: 163-170, 2017.

37. Li Y, Sun X, LaMont JT, Pardee AB and Li CJ: Selective killing of cancer cells by $\beta$-lapachone: Direct checkpoint activation as a strategy against cancer. PNAS 100: 2674-2678, 2003.

This work is licensed under a Creative Commons Attribution-NonCommercial-NoDerivatives 4.0 International (CC BY-NC-ND 4.0) License. 